\title{
Ständischer Verfall und industrielle Mobilisierung. Die Arbeiter*innenschaft in Wiener Neustadt und dem Viertel unter dem Wienerwald
}

\begin{abstract}
Die Industrialisierung ist ein vieldimensionaler historischer Prozess, der das Leben vieler Menschen einem enormen Veränderungsdruck aussetzte. Im Zentrum dieses Prozesses standen die Entwicklung kapitalistischer Produktionsverhältnisse und die Entstehung überregionaler Märkte. Die Folge war eine Forcierung eines Prozesses des Zur-Ware-Werdens, eine Vermarktlichung der menschlichen Arbeit. Die Lohnarbeit wurde somit schrittweise zum zentralen Element der Produktion. Weite Kreise unterschiedlicher handarbeitender und randständiger sozialer Gruppen verloren ihre außerkapitalistische Subsistenzbasis und waren diesem Veränderungsprozess ausgesetzt. Sie wurden so in neue Arbeits- und somit Lebensverhältnisse gezwungen. Damit verbunden entstand eine neue soziale Schichtung und Formierung der Gesellschaft für die der Begriff der „Klasse“ ein zentrales Element der Beschreibung der neuen ökonomischen Verhältnisse und sozialen Positionen in diesen wurde. Dieser Artikel beschreibt die Entstehung der „Arbeiterschaft“ als neue soziale Schicht, als „Klasse“ am Beispiel des Viertels unter dem Wienerwald, das ein Zentrum der Industrialisierung in der Habsburgermonarchie war.
\end{abstract}

The Decline of the Estates and Industrial Mobilization. Workers in Wiener Neustadt and the Quarter below the Vienna Woods. Industrialization is a multi-dimensional historical process that put the lives of many people under enormous pressure to change. At the centre of this process stood the development of relationships of capitalist production and the emergence of supraregional and national markets. The result was an intensification of a process of commodification, a marketing of human work. As wage labour gradually became the central element of production, large groups of different manual workers and marginalized social groups lost their non-capitalist subsistence base and were exposed to this transformation process. This forced them into new working and living conditions. Associated with this was a new social stratification and formation of society for which the term "class" became a central element in the description of the new economic conditions and social positions within them. This chapter describes the emergence of the "working class" as a new social class using the example of the Viertel unter dem Wienerwald, a centre of industrialization in the Habsburg Monarchy.

Keywords: defeudalisation, commodification of labour, industrialization, class formation, social conflict 